\title{
Bilateral ptosis with complete ophthalmoplegia
}

\author{
Charmaine Chircop, Malcolm Vella
}

Department of Neurosciences, Mater Dei Hospital, Msida, Malta

\section{Correspondence to}

Dr Charmaine Chircop, charmaine.cassar@yahoo.co.uk

To cite: Chircop C, Vella M. BMJ Case Rep Published online: [please include Day Month Year] doi:10.1136/ bcr-2013-008852

\section{DESCRIPTION}

An 89-year-old woman was referred to the accident and emergency department with droopy eyelids. The onset of symptoms coincided with the initiation of clarithromycin prescribed for a respiratory tract infection. She was also reported to have a change in the quality of her voice and was choking on fluids. On examination she had bilateral ptosis and complete ophthalmoplegia. Pupils were unreactive but the patient had undergone bilateral cataract surgery in the past. Her speech was dysarthric. Examination of the extremities revealed mild weakness proximally with no definite fatigability and generalised areflexia. Sensory examination was normal. Routine bloods, $\mathrm{CT}$ of the brain and lumbar puncture were unrevealing. A differential diagnosis of the Miller-Fisher variant $^{1}$ of Guillain-Barré syndrome and myasthenia gravis, possibly triggered by the use of macrolide antibiotics, ${ }^{2}$ was made. There was nothing to suggest a diagnosis of botulism. The patient was treated with intravenous immunoglobulins. No improvement was seen with a trial of low dose pyridosytigmine and repetitive nerve stimulation showed no significant decremental response. Acetylcholine receptor antibodies were negative, but anti-GQ1b antibodies were strongly positive at $361 \%$ (normal range $<30 \%$ ) confirming a diagnosis of Miller-Fisher syndrome. The patient recovered fully and returned to baseline condition within 8 weeks (video 1 ).

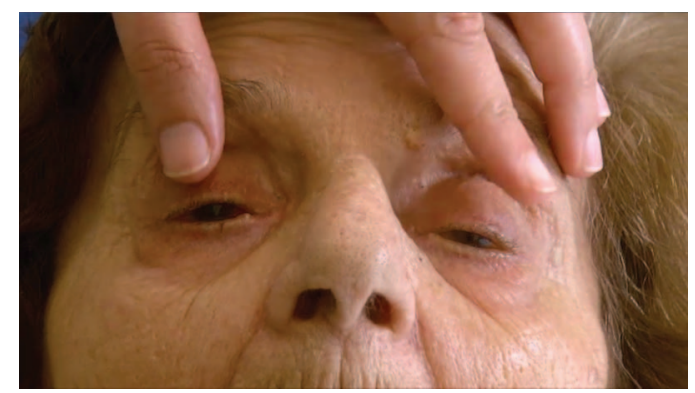

Video 1 Patient with bilateral ptosis and opthalmoplegia.

\section{Learning points}

- Miller-Fisher syndrome accounts for approximately $5 \%$ of Guillain-Barré syndrome and can present with ptosis and complete ophthalmoplegia.

- Acute ophthalmoplegia in Miller-Fisher syndrome is highly associated with serum IgG antibody against $\mathrm{G}_{\mathrm{Q} 1 \mathrm{~b}}$.

- Miller-Fisher syndrome is potentially fully reversible with treatment even in older age groups.

Correction notice This article has been corrected since it was published Online on 18 March 2013. The missing video has now been included.

Competing interests None.

Patient consent Obtained.

Provenance and peer review Not commissioned; externally peer reviewed.

\section{REFERENCES}

1 Mori M, Kuwabara S, Fukutake T, et al. Clinical features and prognosis of Miller Fisher syndrome. Neurology 2001;56:1104-6.

2 Chiba A, Kusunoki S, Obata $H$, et al. Serum anti-GQ ${ }_{1 b}$ IgG antibody is associated with ophthalmoplegia in Miller Fisher syndrome and Guillain-Barré syndrome, Clinical and immunohistochemical studies. Neurology 1993;43:1911.

\footnotetext{
Copyright 2013 BMJ Publishing Group. All rights reserved. For permission to reuse any of this content visit http://group.bmj.com/group/rights-licensing/permissions.

BMJ Case Report Fellows may re-use this article for personal use and teaching without any further permission.

Become a Fellow of BMJ Case Reports today and you can:

- Submit as many cases as you like

- Enjoy fast sympathetic peer review and rapid publication of accepted articles

- Access all the published articles

- Re-use any of the published material for personal use and teaching without further permission

For information on Institutional Fellowships contact consortiasales@bmjgroup.com

Visit casereports.bmj.com for more articles like this and to become a Fellow
} 